\title{
LANDSCAPE DYNAMICS CHANGES OF THE PROTECTED MARY VALLEY, TURKEY
}

\author{
DEMIR, S. \\ Bursa Technical University, Forestry Faculty, Landscape Architecture Department \\ Bursa, Turkey \\ (e-mail: sara.demir@btu.edu.tr; phone: +905553564771)
}

(Received $4^{\text {th }}$ Dec 2018; accepted $20^{\text {th }}$ Feb 2019)

\begin{abstract}
This paper presents the case of Mary Valley's protected catchment, which is located in the northeast Black Sea Region of Turkey, and was declared a national park in 1987. The study area has sensitive ecosystems, with rare and endangered endemic plants. Nevertheless, current unsustainable economic activities, uncontrolled tourism and population migration have adversely affected its sensitive ecological integrity. This research aims to monitor and analyze the landscape dynamics changes of land use-land cover and landscape structure by change detection and landscape metrics in 1987, 1998, 2009 and 2016. The relationship between LULC and habitat changes linked to those of endemic plants were aimed to be determined. The findings indicated that forest areas with the highest loss transformed into grassland, shrubland and bare land areas, while bare land experienced the highest gain. However, forest area has the highest and bare land has the lowest habitat function. Additionally, endemic plant habitats have an inverse relationship with the habitat value of forest and bare land areas and a direct relationship with shrublands. These unsuitable changes can adversely pressure the sensitive landscape dynamics of Mary Valley protected area. Thus, landscape dynamics and their changes should be monitored to protect and manage for the sustainable development of Mary Valley resources.
\end{abstract}

Keywords: environmental monitoring, landscape dynamics change, habitat function, landscape metrics, protected area

\section{Introduction}

Landscape is an area where there is action, interaction and various relationships between natural and/or cultural resources (CE, 2000). These effects and relationships inevitably cause a change in landscape dynamics. Since the dawn of time, the change of landscape patterns, landscape sensitivity and landscape dynamics have been generated by natural disasters and unsustainable, unplanned decision making (Antrop, 2000). The idea to analyze landscape changes has been raised for the determination of the complex and significant interactions among natural, cultural and social processes (Esbah et al., 2010; Martinuzzi et al., 2015). Thus, the need for monitoring and analyzing the temporal and spatial changes of natural and cultural areas and providing for their sustainable development have become essential concerns in the last few decades (Lausch and Herzog, 2002).

Protected areas are valuable components for biodiversity, culture and history. Nevertheless, they have been under pressure due to uncontrolled and unmanaged land use and land cover change (LULCC) caused by anthropogenic activities that are mainly influenced by socioeconomic, political and technological factors (Braimoh, 2006; Esbah et al., 2010; Mariota et al., 2013; Scullion et al., 2014). Thus, monitoring and assessment are important for sustainable land management because they can define environmental trends that can be used in the planning of future endeavors in protected areas, solving problems of the landscape, and finally sustainably using resources (Estes et al., 2012; Angonose and Grau, 2014; Tian et al., 2014; Oinam et al., 2018). 
LULCC is a key driver of global landscape change and can describe the relationship between humans and the use of the surrounding land (Fichera et al., 2012; Scullion et al., 2014). LULCC in landscape patterns is related to urban and population growth, negative impacts of anthropogenic uses, socioeconomic, political and technological variables. It increases impervious land use and deforestation and decreases agricultural and grassland areas (Seto et al., 2005; Bozkaya et al., 2015). Effective monitoring and assessment of LULC is a suitable way to assess landscape mechanisms and ecological processes, provide ecological and cultural sustainability, understand sensitivities of landscapes based on erosion and flood risk, biodiversity and habitat potential or loss, soil, water and air quality, predict future change in landscape patterns, mitigate undesirable effects on landscape resources and solve problems of landscape dynamics (Estes et al., 2012; Fichera et al., 2012; Tian et al., 2014; Demir, 2017).

Landscape ecology is focused on characterizing habitat function using landscape metrics at the patch, class and landscape level, i.e. number, size, density, edge and shape of patches (McGarigal and Marks, 1995; Lausch and Herzog, 2002; Seto and Fragkias, 2005). Overall landscape is defined by analyzing the landscape structure to understand its habitat function using landscape metrics (Turner et al., 2001; Malaviya et al., 2010; Mairota et al., 2013; Demir and Demirel, 2018). Therefore, these metrics can describe the distribution of landscape disturbance and explain sustainable landscape development and landscape patterns and dynamics (Neel, 2008; Esbah et al., 2010, Fan et al., 2018). Understanding landscape dynamics is associated with landscape functions and changes (Seto and Fragkias, 2005; Ghosh et al., 2012; Bruton et al., 2016). LULCC integrated with landscape metrics generates useful information for land use researchers, landscape and urban planners, decision and policy makers that can be effectively used for landscape planning and management (Esbah et al., 2009; Malaviya et al., 2010; Fichera et al., 2012). Due to this, monitoring and analyzing LULCC and landscape structure have gained attention internationally in recent years (Lausch and Herzog, 2002; Kara et al., 2013).

Unsustainable land use can damage and reduce biological diversity and culturalhistorical resources of protection areas (Martinuzzi et al., 2015). Therefore, they cannot be assessed in isolation, separately from their surroundings (Demir et al., 2016) because ecological processes form an integrated system that is not limited by administrative boundaries. This study monitored and analyzed Altindere Valley National Park and its surrounding Mary Valley catchment, based on ecological boundaries, located in the Maçka District of Trabzon, Turkey. With its protected ecological and cultural resources, Mary Valley has gained national and international tourism potential. Especially the historical Sumela Monastery is visited each year by Orthodox Christians from around the world. It is host to 31 endemic plants species (Salapaş, 2002; Uzun, 2002). Although there are many ecological, cultural and touristic attractions in the park, the human population of the study area diminished by about 25\% from 1987 to 2016 due to migration to urban areas (TURKSTAT, 2016). This study monitored and analyzed temporal and spatial LULCC and habitat function in the protected Mary Valley. In this context, this study's objectives are to determine temporal habitat value based on landscape structure analysis using landscape metrics (1) and to identify the relationships among LULCC, habitat function and endemic plant distribution areas (2). To reach this aim, temporal landscape dynamics were evaluated to understand the changes of LULC types, endemic plant habitats and their value. The use of landscape structure analysis integrated with the normalization method and determining the effects of LULC changes 
on sensitive endemic plant habitats were the primary objectives of this research. Therefore, the findings of this research can be an example for Turkey and other developing counties to support ecological and cultural integrity of protected areas.

\section{Methodology}

The research process included the characterizing the study area, data collection, image pre-processing, image classification, determining and comparing LULCC and determining habitat function using landscape structure metrics analysis (Figure 1).

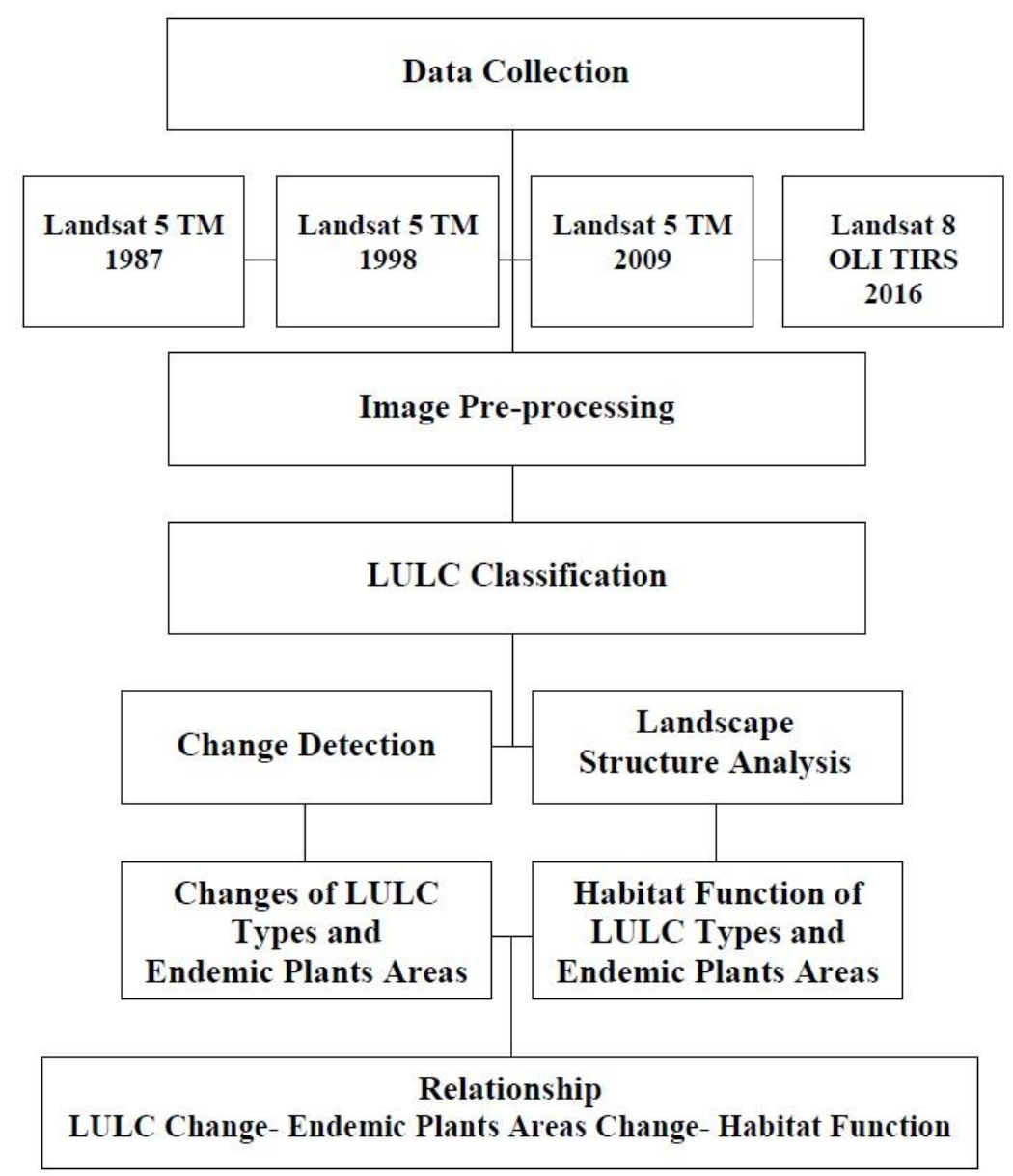

Figure 1. Flowchart of the research process

\section{Study area}

Mary Valley, located in the Maçka District of Trabzon Province in Turkey's Northeast Black Sea Region, lies in a catchment area of approximately 7,802 hectares $\left(40^{\circ} 45^{\prime} 48^{\prime \prime}-40^{\circ} 37^{\prime} 17^{\prime \prime} \mathrm{N}, 39^{\circ} 35^{\prime} 55^{\prime \prime}-39^{\circ} 42^{\prime} 26^{\prime \prime}\right.$ E) (Figure 2). It is a rural area with six traditional villages and plateau settlements on the steep and deep valley, with a rich natural, cultural and historical landscape. Therefore, Mary Valley is one of the most internationally and nationally important protected areas and tourism destinations of Turkey. 4,468 hectares of the study area were declared as the Altindere National Park in 1987 by the Ministry of Environment and Urbanism. 


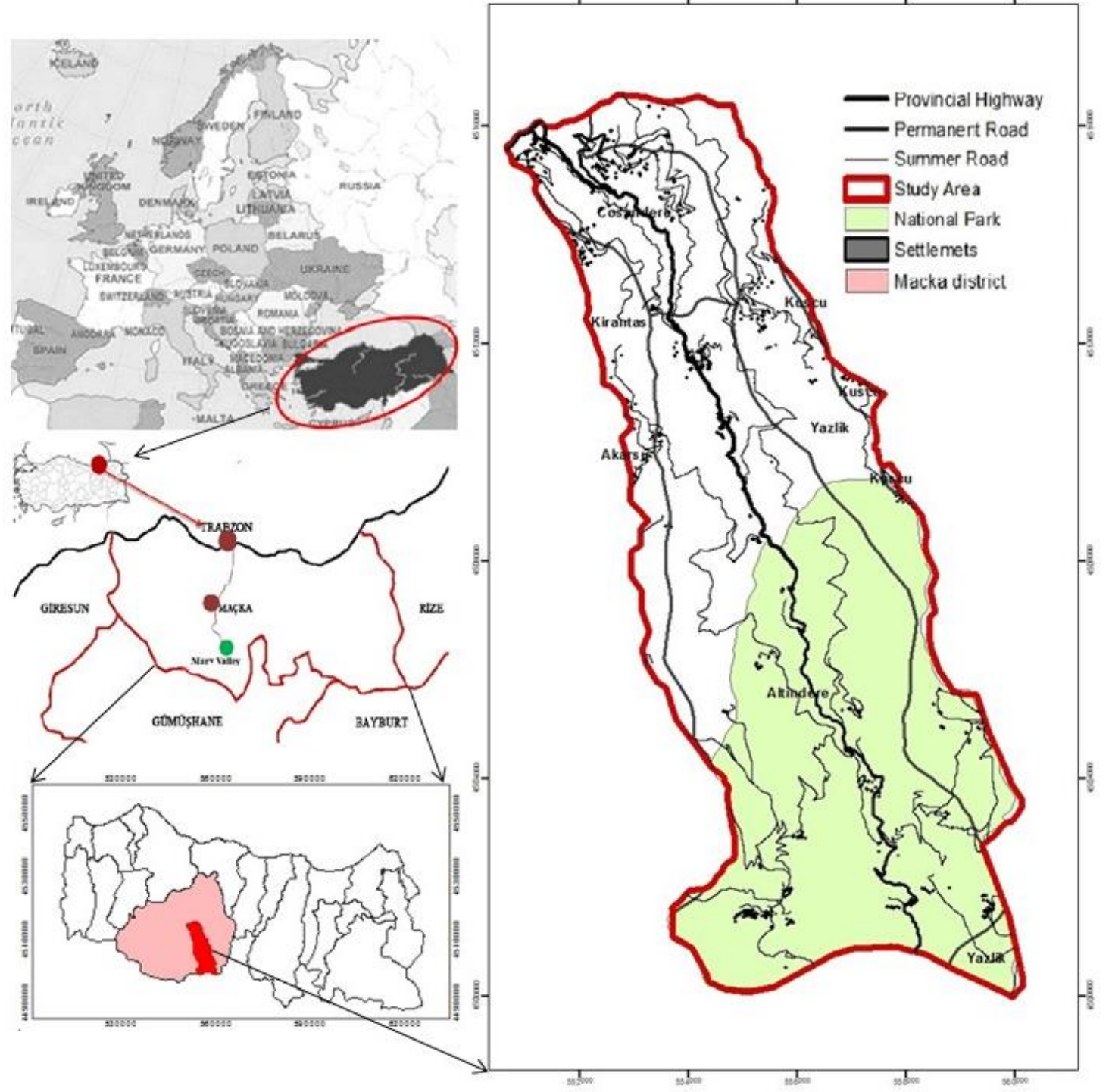

Figure 2. The study area of Mary Valley, Turkey

A difference in elevation from 480 meters to 2,718 meters shapes the area's topography, climate and vegetation (Doganay, 2003; Demir, 2017). The study area includes different kinds of ecosystems including riparian buffers, dense broadleaf forests $(1,350 \mathrm{~m}-1,750 \mathrm{~m})$, coniferous forests $(1,750 \mathrm{~m}-2,000 \mathrm{~m})$, and alpine meadows (2,000 $\mathrm{m}$ and higher). It hosts 31 endemic plants species (App. 1) that are declared on the red list of IUCN as threatened species (Salapaş, 2002; Uzun, 2002; Demir, 2017). It has been designated as an Important Bird Area concerning Eastern Europe's bird migration (BirdLife International, 2015; Development Plan, 2005). The historical Sumela Monastery has an archaeologically and historically important cultural landscape value that manifests in the religious ceremonies of monks and pilgrims (Zaman, 2010; Demir et al., 2015).

The current land cover types of the study area include forests, shrublands, grasslands, croplands, bare land and settlements. The main economic activities are tourism, agriculture, forestry and livestock breeding. Forestry and agricultural activities are 
restricted within the national park's boundaries. These reasons lead to the migration of locals to big cities, and the population of study area diminished from 4,142 to 1,602 people between 1987 to 2016 (TURKSTAT, 2016). Additionally, the conservation status Mary Valley was under changed from 1972 to 1998. Mary Valley has gained national and international conservation value and tourism potential due to its wide range of natural and cultural resources. Thus, ecology-based tourism has been proposed for this protected catchment area by the KAMAG (2011) and in DOKA (2012) projects and by several studies (Demir et al., 2015; Pirselimoğlu and Demirel, 2015a, 2015b). The changes of LULC and habitat can be a determining factor in promoting sustainable development of this area.

\section{Data collection}

Three different Landsat 5 TM images taken on September 8, 1987, September 22, 1998, and September 4, 2009, in addition a Landsat 8 OLI TIRS image taken on September 3, 2016 were downloaded from the USGS website and used in this research to examine LULCC in Mary Valley. The spatial resolution of Landsat 5 TM images and the Landsat 8 OLI TIRS image is 30 meters. All these images had cloud cover of less than $5 \%$. Moreover, one rectified digital aerial photo with a spatial resolution of $3 \mathrm{~m}$ taken on August, 122013 and a map with a spatial resolution of $30 \mathrm{~m}$ called Globeland 30-N37 from September 16, 2010 was used for visual interpretation and accuracy assessment (GLC30, 2015). Demographic data (TURKSTAT, 2016) and endemic plant species data (Salapaş, 2002; Uzun, 2002) were examined for habitat and local population change. ERDAS 2014 software was used for image pre-processing, classification and haze reduction. ENVI+IDL programs were used to reduce the black line gaps of the images based on the Landsat gap fill process. ARCGIS 10.2 was used for geometric corrections, converting raster data to vector data and determining the LULCC. FRAGSTAT 4.2 (McGarigal et al., 2012) was used to determine habitat value of land cover types using landscape structure metrics.

\section{Image pre-processing}

The 5 TM images taken in the year 1987, 1998 and 2009, in addition to the Landsat 8 OLI TIRS image taken in the year 2016 were evaluated directly for image preprocessing. For this step, Image pre-processing was used to eliminate band combination based on stack layers, top of atmospheric radiances (TOA), atmospheric correction, and for haze reduction. Firstly, the digital number (DN) layers were combined with the stack layer modeler. For next step, a top of atmospheric radiance and reflectance computation (TOA) modeler was created for each image to minimize atmospheric effects (Özyavuz et al., 2011; Tian et al., 2014). The radiative transfer model was used for the atmospheric correction of these four satellite images from 1987, 1998, 2009 and 2016 using the simulation of the satellite signal in the solar spectrum (5S) to compute the atmosphere's attenuation of the solar radiation that reflected radiation or radiance from a surface. Then all the values were evaluated for the satellite images, separately. The Landsat images were geometrically corrected and registered in the Universal Transfer Mercator projection system (datum WGS 84, zone $37 \mathrm{~N}$ ) for geometric correction. The Landsat fill gap was used to eliminate and reduce the black line gap and haze effects in the visible bands of Landsat images (Yale, 2015) to enhance the accuracy of classification. Images of four different times were used to determine landscape dynamics changes through LULC and landscape structure analysis. 


\section{Image classification}

The classification process groups pixels that have similar spectral values (Kara et al., 2013; Bozkaya et al., 2015). This research was carried out using the maximum likelihood supervised classification algorithm to detect land use and land cover types. In this process, 342, 329, 303 and 325 pixels were selected for 1987, 1998, 2009 and 2016, respectively. After that, forest areas (deciduous and coniferous), shrublands, grasslands, bare land (gravel and bare ground) and croplands were identified as land use and land cover classes. These classified data were compared with the GlobeLand 30-N27 map and the digital aerial photo (2013) using on-screen digitizing to improve the accuracy rates of the classification maps and solve the mixed pixel problem. Overall accuracy was calculated using 800 independent test pixels. The statistical results were $94 \% 94 \%$ $92 \%$ and $93 \%$ respectively for the 1987, 1998, 2009 and 2015 classified images.

\section{Change detection}

Change detection was used to compare two years using from-to analysis (Francisco and Hochschil, 2012; Tian et al., 2014). It is the most effective technique for detecting the differences between two images and demonstrates the transformation of LULCC by post-classification comparison (Fichera et al., 2012; Kara et al., 2013; Hussain et al., 2018). This comparison indicates the percentage of each class on diagonal and offdiagonal axes (Congalton et al., 2014; Tian et al., 2014; Rawat and Kumar, 2015). The changes in LULCC were determined and described for three intervals: 1987-1998, 1998-2009 and 2009-2016. According to Leitao et al. (2006), Esbah et al. (2009, 2011), Erdogan et al. (2013) an at least 100 meter buffer zone area is a viable way of protecting the sensitive core zone of a habitat. Therefore, this zone was created for the point data of endemic plant species in order to detect and monitor the LULCC (Leitao et al., 2006; Esbah et al., 2011; Erdogan et al., 2013) of these areas from 1987 to 2016. This process was summarized in terms of net change, total change, persistence, gross gains, losses and swaps in LULCC (Braimoh, 2006; Angonese and Grau, 2014). After detecting the different areas of persistence, gain and loss for LULCC, these areas were associated with the endemic plant habitats. This post- classification method (from-to) was used by comparing images taken at different times to monitor the transitions of LULC and endemic plant habitats.

\section{Landscape structure}

Landscape metrics analysis was used to assess the habitat function and landscape changes for the quantification of landscape pattern to compute the complexity of landscape structures (Leitao et al., 2006; Esbah et al., 2010; Gökyer, 2013). In this research, 16 landscape metrics were used in FRAGSTAT 4.2 software at the class level for four LULCC classified map-years (Table 1). The metrics were categorized in four groups according to their characteristics (McGarical et al., 2002): 1) area/edge metrics; including percentage of landscape (PLAND), total edge (TE), edge density (ED), patch number (PN), patch density (PD), mean patch size (MPS), area weighted patch size (AWP); 2) shape metrics, including mean size index (MSI), area weighted mean size index (AWMSI), area weighted mean perimeter-area ratio (MPAR), area weighted mean fractal (FRAC_AM); 3) core metrics, including total core area (TCA), mean core area index (CAI_MN), and 4) the isolation/contiquity metrics, including mean euclidean nearest neighbors distance (ENN_MN), mean contiquity (CONTIG_MN). 
Table 1. Explanation of relationship between landscape metrics and habitat function (Turner et al., 2001; Esbah et al., 2009; Demir and Demirel, 2018)

\begin{tabular}{|c|c|c|}
\hline Landscape Metrics & Symbol & Explanation \\
\hline Percentage of Landscape & PLAND & $\begin{array}{l}\text { It measures the percentage of the each land cover } \\
\text { class according to all landscape cover classes. }\end{array}$ \\
\hline $\begin{array}{l}\text { Mean Patch Size } \\
\text { Area Weighted Mean Patch Size } \\
\text { Patch Number } \\
\text { Patch Density }\end{array}$ & $\begin{array}{l}\text { MPS (AREA_MN) } \\
\text { AWMPS (AREA_AM) } \\
\text { PN } \\
\text { PD }\end{array}$ & $\begin{array}{l}\text { MPS measures the size of discrete patches } \\
\text { summarized across all patches of a particular land } \\
\text { cover class. If the patch size is bigger, it has more } \\
\text { habitat potential. If it is used by Patch Number } \\
\text { (PN) and Patch Density (PD), it can serve as a } \\
\text { fragment. Displays the magnitude of the presence } \\
\text { of similar patches in the landscape, indicates } \\
\text { isolation if PD decreases. More patches (PN) } \\
\text { mean more boundaries between land cover } \\
\text { classes, which can mean barriers to movement } \\
\text { between habitats. MPS and PD are directly } \\
\text { proportional and PN is inversely proportional to } \\
\text { habitat function. } \\
\text { MPS is interpreted better by PLAND, PN and } \\
\text { PD. }\end{array}$ \\
\hline $\begin{array}{l}\text { Total Edge } \\
\text { Edge Density }\end{array}$ & $\begin{array}{l}\text { TE } \\
\text { ED }\end{array}$ & $\begin{array}{l}\text { Total Edge (TE) is the total edge numbers for } \\
\text { each landscape class. Edge Density (ED) is the } \\
\text { total length of per hectare for each landscape } \\
\text { class area. TE and ED are inversely proportional } \\
\text { to habitat function, because more edges mean } \\
\text { higher possibility of edge effects. Edge effects } \\
\text { alter vegetation structure and animation } \\
\text { abundance. }\end{array}$ \\
\hline $\begin{array}{l}\text { Mean Size Index } \\
\text { Area Weighted Mean size Index } \\
\text { Area Weighted Mean Perimeter-area } \\
\text { Ratio }\end{array}$ & $\begin{array}{l}\text { MSI (SHAPE_MN) } \\
\text { AWMSI (SHAPE_AM) } \\
\text { MPAR } \\
\text { (PARA_AM) }\end{array}$ & $\begin{array}{l}\text { It measures the average of the mean patch shape } \\
\text { for each land cover class. AWMSI and MSI are } \\
\text { related to the complex geometric shapes of a } \\
\text { patch because these affect the edge effects and } \\
\text { cross boundaries. Linear, corridor-like, lobed, } \\
\text { complex and convoluted patch shapes have a } \\
\text { higher amount of boundaries than round, compact } \\
\text { and simple patch shapes. Rounded, compact and } \\
\text { simple patch shapes garner a higher habitat } \\
\text { potential than others because more boundaries } \\
\text { mean higher possibility of edge effects. If the } \\
\text { number is close to 1, it means the class can have a } \\
\text { higher habitat value. Most of shape metrics have } \\
\text { a relationship with perimeter-area metrics. MPAR } \\
\text { is inversely proportional to habitat function. }\end{array}$ \\
\hline Area Weighted Mean Fractal & FRAC-AM & $\begin{array}{l}\text { It measures the total edge length of the patches of } \\
\text { each land cover class. It displays the } \\
\text { fragmentation of habitat. If the number is smaller, } \\
\text { it means the fragmentation is not so severe. } \\
\text { FRAC-AM is inversely proportional to habitat } \\
\text { function. }\end{array}$ \\
\hline Mean Contiquity & CONTIG_MN & $\begin{array}{l}\text { It measures the average possibility of neighbors } \\
\text { (contiguity) of each land cover class. CONTIG- } \\
\text { MN is inversely proportional to habitat function. }\end{array}$ \\
\hline $\begin{array}{l}\text { Mean Euclidean Nearest Neighbors } \\
\text { Distance }\end{array}$ & ENN_MN & $\begin{array}{l}\text { It measures the average distance of the nearest } \\
\text { neighbors (contiguity) of each land cover class. } \\
\text { ENN_MN is inversely proportional to habitat } \\
\text { function. }\end{array}$ \\
\hline $\begin{array}{l}\text { Total Core Area } \\
\text { Mean Core Area Index }\end{array}$ & $\begin{array}{l}\text { TCA } \\
\text { CAI_MN }\end{array}$ & $\begin{array}{l}\text { It measures the total core area of each landscape } \\
\text { classes. } 100 \mathrm{~m} \text { is based on the core area. It can be } \\
\text { assessed with CAI-MN to display the detection of } \\
\text { habitat function of each land cover class. }\end{array}$ \\
\hline
\end{tabular}


The directly and inversely proportional metrics that affect habitat function were evaluated separately for each category. Finally, one of the well-known linear normalization methods called Min-Max method was used to normalize the data linearly. Minimum; refers to the lowest value, maximum; refers to the highest value that data can receive. The Min-Max normalization method (Equation 1) sorts data in the range of 0 to 1 (Wang and Cumming, 2011; Yavuz and Deveci, 2013). Data is calculated according to the following Equation 1:

$$
x=\frac{x_{i}-x_{\min }}{x_{\max }-x_{\min }}
$$

In this formula $\mathrm{x}^{\prime}$ is normalized data, $\mathrm{x}_{\mathrm{i}}$ is input value, $\mathrm{x}_{\min }$ is the smallest and $\mathrm{x}_{\max }$ is the largest number in the input set (Equation 1). In this context, Min-Max normalization method was preferred to generalize objectively the range of landscape structure metrics values of each LULC type.

\section{Results and discussion}

\section{Land use and land cover change}

The LULC types in the study area consist of forests, grasslands, bare land, shrublands and croplands. According to the LULC distributions from 1987 to 2016, the dominant LULC types were forests and grasslands (Figure 3). The LULC types gained bare land at the cost of losing forest, grassland, shrubland and cropland, respectively. Forests decreased from $49.87 \%$ in 1987 to $43.92 \%$ in 2016 , while bare land increased significantly. In 2016, the forests were still dominant followed by croplands. The bare land area increased significantly in 2016 compared to previous years, while forests declined sharply in 2016 (Figure 4).

The change detection indicated the amounts of net change, total change, persistence, gains, losses and swaps of LULCC types from 1987 to 2016. Table 2 shows that grasslands had the highest total change (13.06\%) and highest swap $(12.10 \%)$ in terms of gain and loss amounts. Cropland had the lowest total change (gain+loss) and the lowest swap amounts. The highest net change (gain-loss) of LULCC belonged to bare land, and the lowest change was that of croplands. Forests experienced the highest loss with 580.23 ha, whereas bare land experienced the highest gain with 615 ha (Table 2).

Eventually, the LULC types of the research area include forest, grassland, bare land and shrubland. Forest and grasslands are the main LULC types of this research. Loss of forest is most likely due to lumber production and the expansion of the road network for villages, summer homes and ski centers, whereas gain in bare land is due to the transformation of grasslands. Cropland areas decreased constantly from 1987 to 2016 (Table 2). The main causes of this decline were the limitations on agricultural and forestry activities in the national park, and local migration. Although forestry activities were limited, the forestry area had a similar decreasing trend due to hydroelectric power plants, road networks, deforestation and floods. In these cases, forest areas were transformed to grasslands, shrublands and bare land within 29 years, showing that, besides anthropocentric activities, lack of conservation and management strategies negatively affected LULCC. 

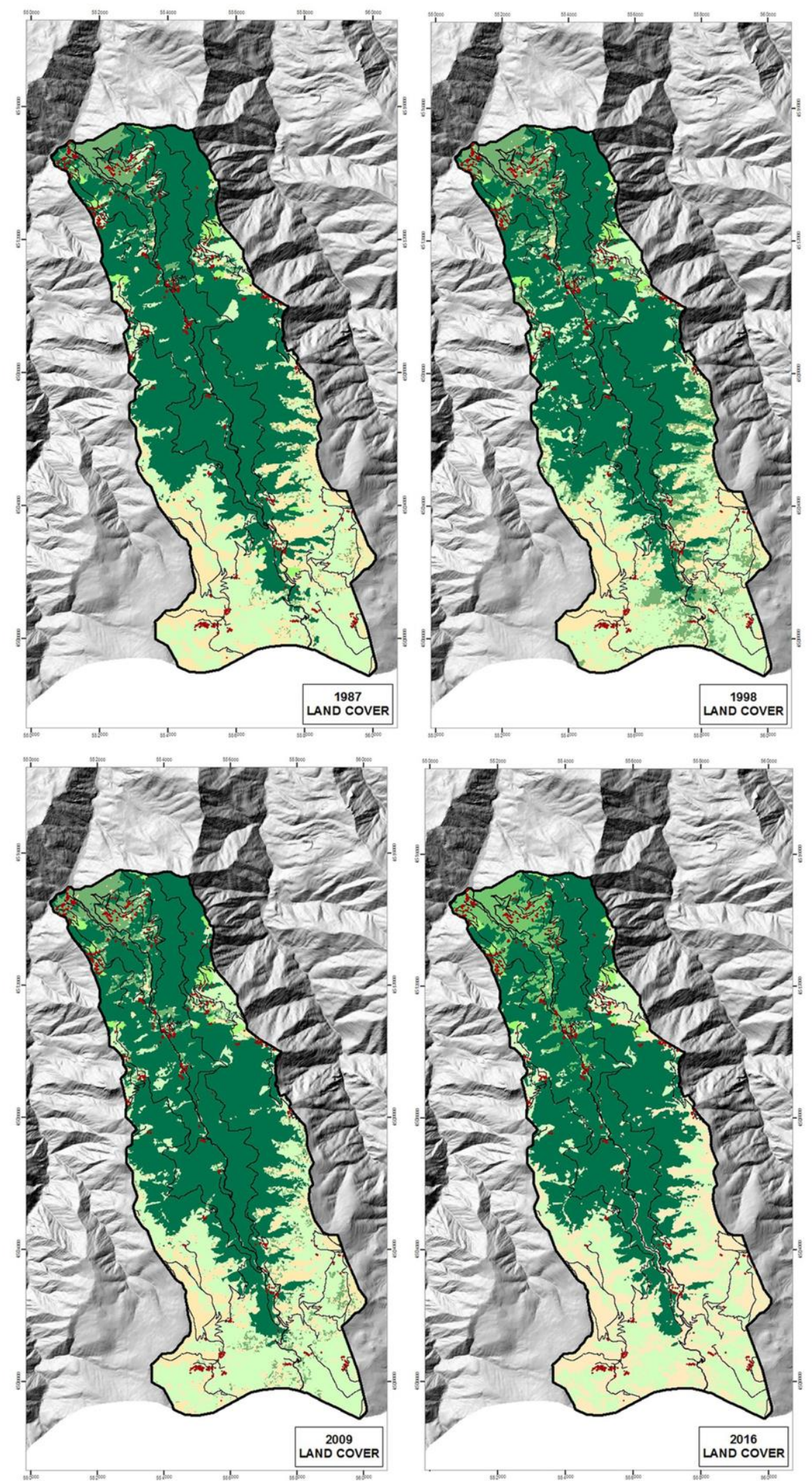

Legend

- Roads

Study area

Settlements

Bareland Cropland

Forest Grassland $\square$ Shrub

Figure 3. LULC (land use-land cover) classification of 1987-1998-2009-2016 


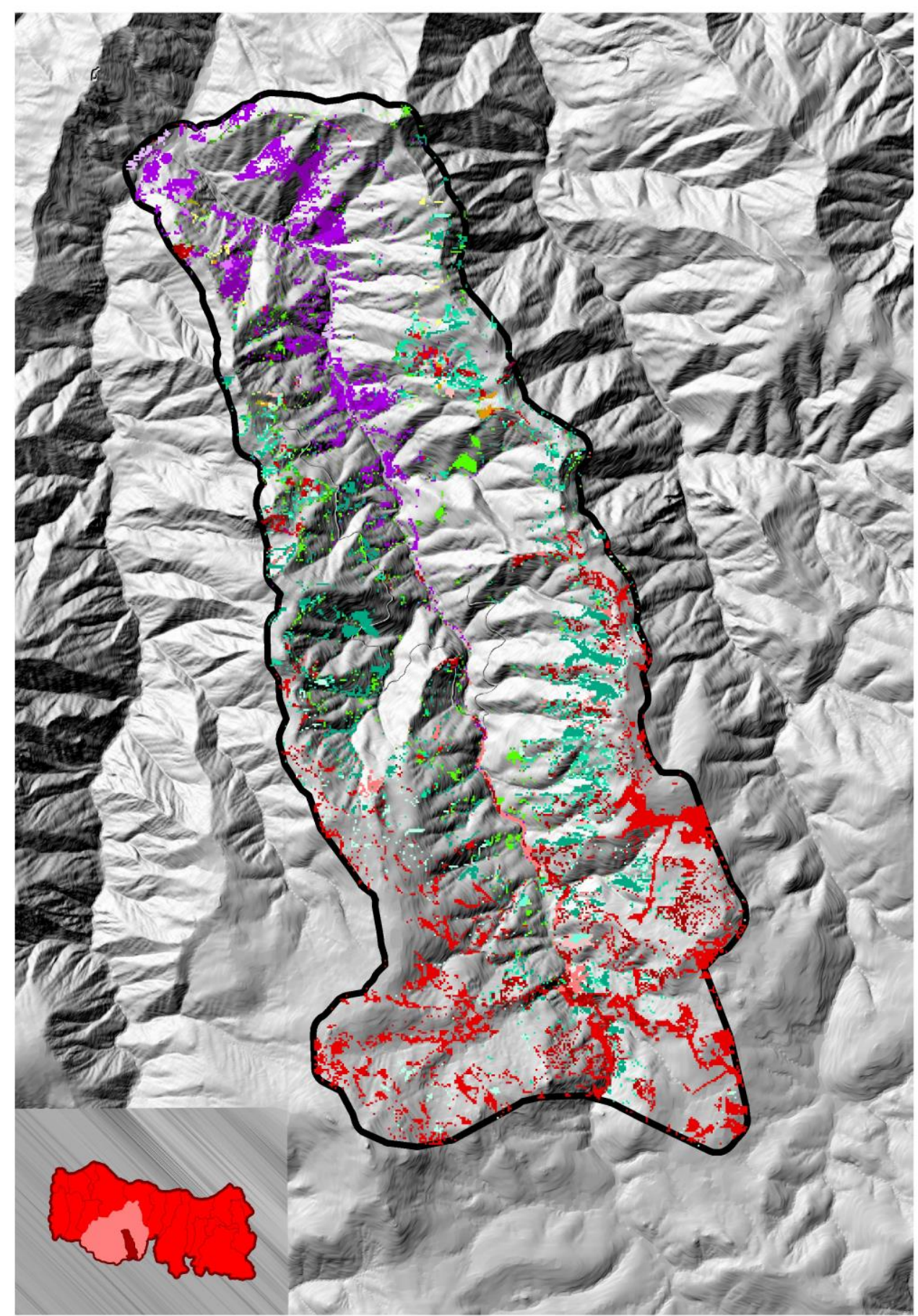

\section{Legend}

Change Class from 1987 to 2016
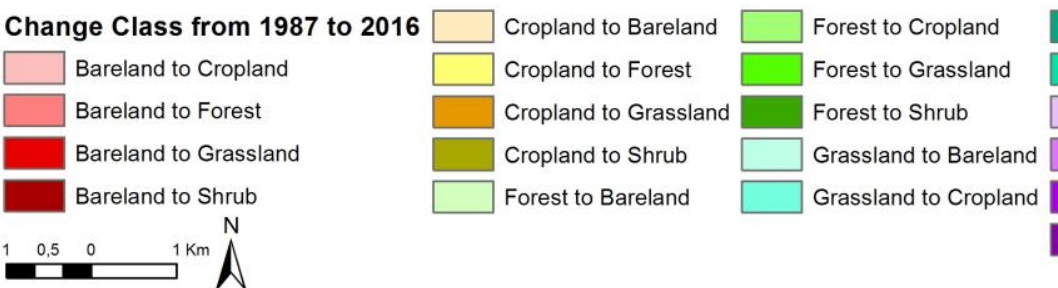

Grassland to Forest Grassland to Shrub Shrub to Bareland Shrub to Cropland Shrub to Forest Shrub to Grassland

Figure 4. Transition of LULC (land use-land cover) types from 1987 to 2016 
Table 2. Change detection and summary of LULC (land use-land cover) changes

\begin{tabular}{|c|c|c|c|c|c|c|c|c|}
\hline \multicolumn{9}{|c|}{ Change detection of LULC (ha) } \\
\hline \multicolumn{9}{|c|}{2016 (ha) } \\
\hline \multirow{8}{*}{ 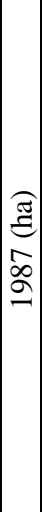 } & $\begin{array}{c}\text { LAND } \\
\text { COVER }\end{array}$ & FOREST & $\begin{array}{l}\text { GRASS- } \\
\text { LAND }\end{array}$ & $\begin{array}{l}\text { SHRUB- } \\
\text { LAND }\end{array}$ & $\begin{array}{l}\text { BARE } \\
\text { LAND }\end{array}$ & $\begin{array}{l}\text { CROP- } \\
\text { LAND }\end{array}$ & $\begin{array}{l}\text { Total } \\
1987\end{array}$ & Loss \\
\hline & FOREST & 3310.56 & 260.82 & 235.62 & 76.95 & 6.84 & 3890.79 & $\underline{580.23}$ \\
\hline & \multirow{4}{*}{$\begin{array}{l}\text { GRASSLAND } \\
\text { SHRUB } \\
\text { BARELAND } \\
\text { CROPLAND }\end{array}$} & 73.35 & 1682.28 & 99.36 & 367.56 & 6.57 & 2229.12 & 546.84 \\
\hline & & 36.63 & 131.49 & 375.75 & 159.39 & 3.24 & 706.50 & 330.75 \\
\hline & & 1.80 & 63.18 & 3.51 & 811.80 & 0.63 & 880.92 & 69.12 \\
\hline & & 4.41 & 16.47 & 6.12 & 11.16 & 55.62 & 93.78 & 38.16 \\
\hline & Total 2016 & 3426.75 & 2154.24 & 720.36 & 1426.86 & 72.90 & 7801.11 & 1565.10 \\
\hline & Gain & 116.19 & 471.96 & 344.61 & $\underline{615.06}$ & 17.28 & 1565.10 & $20.06 \%$ \\
\hline \multicolumn{9}{|c|}{ Summary of LULC changes (\%) } \\
\hline \multicolumn{2}{|r|}{$\begin{array}{c}\text { LAND } \\
\text { COVER }\end{array}$} & Total 1987 & Total 2016 & Gain & Loss & Total Change & Swap & $\begin{array}{l}\text { Absolute value } \\
\text { of net change }\end{array}$ \\
\hline & FOREST & 49.87 & 43.92 & 1.48 & 7.45 & 8.93 & 2.98 & 5.95 \\
\hline & RASSLAND & 28.57 & 27.61 & 6.05 & 7.01 & 13.06 & 12.10 & 0.96 \\
\hline & SHRUB & 9.06 & 9.23 & 4.42 & 4.24 & 8.66 & 8.48 & $\underline{0.18}$ \\
\hline & ARELAND & 11.29 & 18.29 & 7.88 & 0.89 & 8.77 & 1.77 & $\underline{7.00}$ \\
\hline & ROPLAND & 1.20 & 0.93 & 0.22 & 0.49 & 0.71 & 0.44 & 0.27 \\
\hline & Total & 100.00 & 100.00 & 20.06 & 20.06 & 40.13 & 25.77 & 14.35 \\
\hline
\end{tabular}

\section{Endemic plant areas change}

The research area has 31 endemic plants species in the highlands (Figure 5). According to Leitao et al. (2006), Erdogan et al. (2013), Esbah et al. (2009, 2011), a $100 \mathrm{~m}$ wide buffer zone was created to protect the core zone for each sensitive and endangered endemic plant habitat. The species, listed in the IUCN red list category of threatened species, are most often located in grasslands, forests and shrublands. The LULCC affected endemic plants significantly through the increase of bare land and the loss of grasslands and forests. Even though these plants are protected by the IUCN categories, some changes were found in each endemic plant habitat. LULCC adversely affected their habitats and diminished the environmental properties of the buffer area.

The LULCC distributions from 1987 to 2016 showed that grasslands have the most endemic plants (Figure 5), although the highest loss, swap and especially net change amounts were observed in grasslands. Table 3 included that endemic plant occurrence in shrublands, which is the subdominant LULC type, decreased significantly from $8.70 \%$ in 1987 to $1.81 \%$ in 2016 with the highest loss area. It indicated that the endemic plant habitat in shrublands was under threat with this sharp, constant decline trend. The bare land area experienced more gain, on the contrary, grassland, forest and shrubland experienced more loss from 1987 to 2016. 


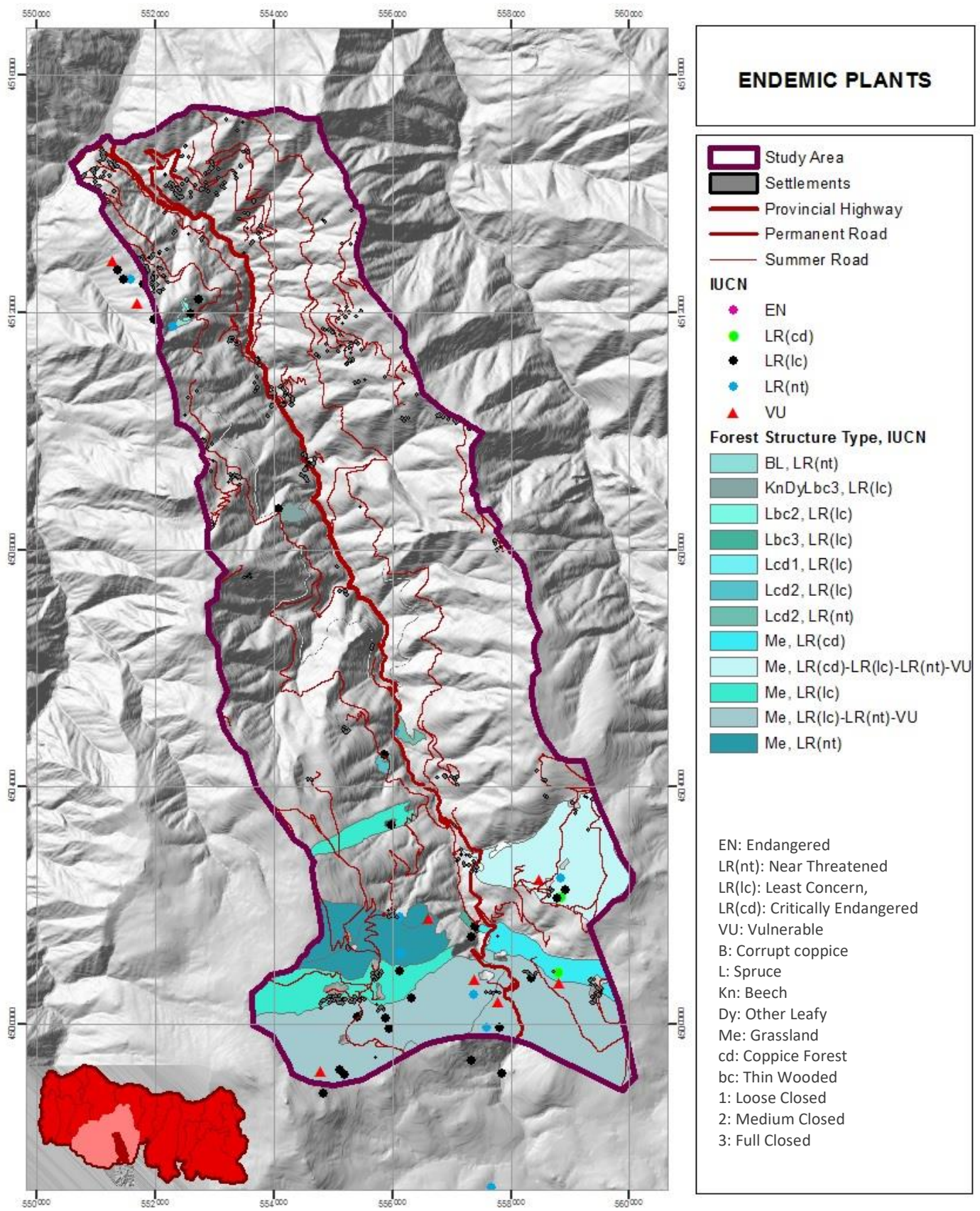

Figure 5. Endemic plants in LULC (land use-land cover) types

Each endemic plant habitat has its own specific ecosystem characteristics (Salapaş, 2002; Uzun, 2002; Scullion et al., 2014). Therefore, the LULCC of the surrounding endemic plants had negative effects on their ecological integrity (Neel, 2008; Esbah et al., 2009). The grassland, forest and shrubland areas, habitats for endemic plants changed dramatically from 1987 to 2016 . These changes can put pressure on sensitive, rare and endangered endemic plants (Ghosh et al., 2012; Demir, 2017). These negative effects on endemic plant areas from 1987 to 2016 can affect the sustainability of local resources in the protected zone. 
LULCC may currently be the most important threat to endemic plants (Neel, 2008; Bozkaya et al., 2015). Conservation plans should be created for tourism and land management and should be supported by local participation to ensure sustainable protection (Malaviya et al., 2010; Francisco et al., 2012; Mairota et al., 2013). In this research, continuous annual data on the population density of endemic plants was missing. Utilizing continuous annual data would enhance understanding of the seasonal distributions of endemic plants.

Table 3. Change detection and summary of endemic plant habitat changes

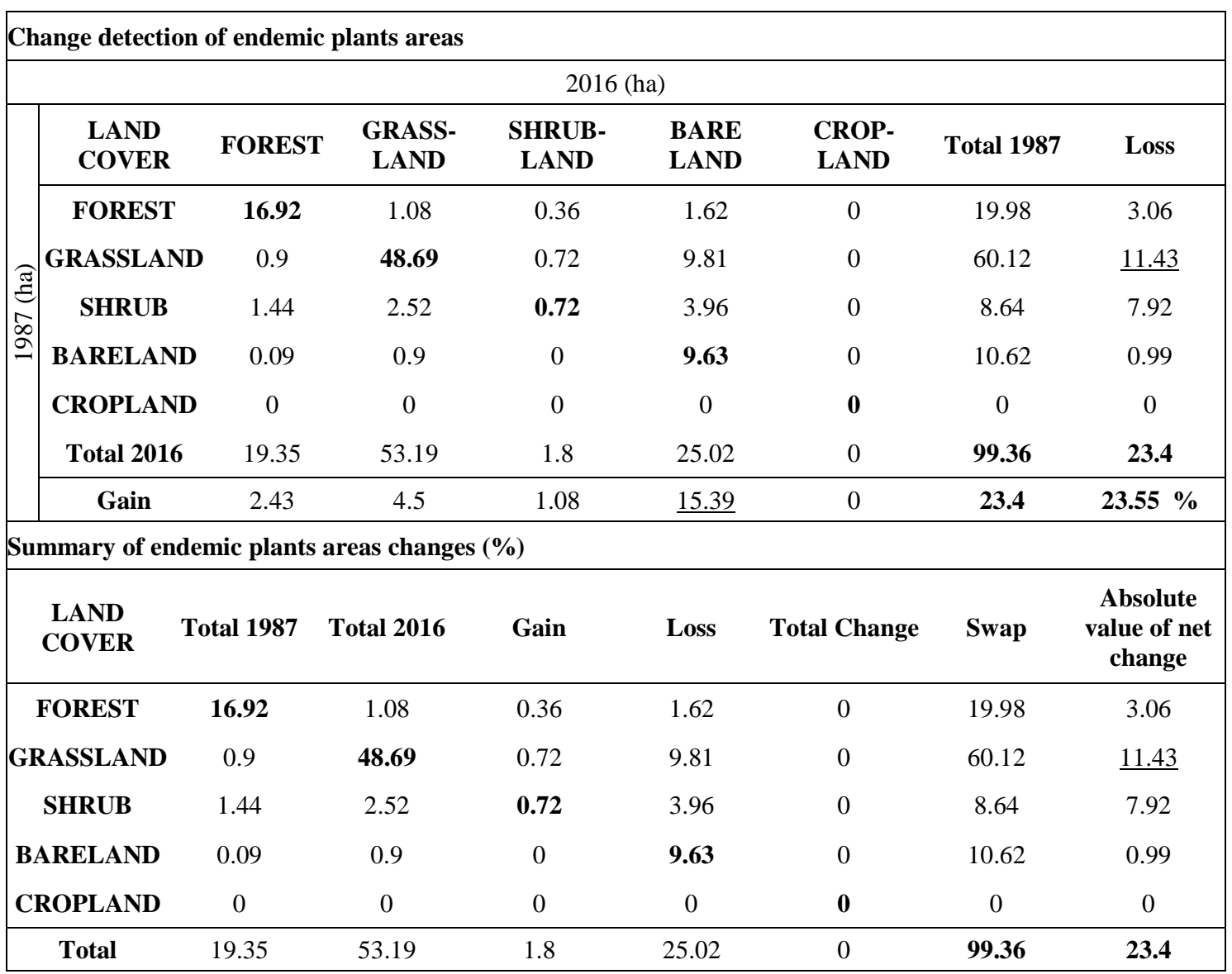

\section{Habitat change of LULC}

Landscape has interaction with and influence on natural and cultural values (CE, 2000). Due to this, monitoring the changes of landscape dynamics has a key role in this research. In this context, the natural and cultural landscape resources of Mary Valley were examined and habitat potential based on landscape sensitivity was determined to observe changes of LULC and endemic plant populations.

The quantification of landscape dynamics of a landscape pattern using landscape metrics is a basic way to determine habitat function and landscape changes (Forman and Godron, 1986; Turner, 2001; Fan et al., 2018). Therefore, the habitat function of the research area was evaluated using landscape structure metrics for LULCC types from 1987 to 2016 in four categories. The landscape metrics grouped in the area/edge metrics class from 1987 to 2016 indicated that the values of TE, ED and PN of grassland and 
cropland are higher; conversely, PD and MPS values are lower than those of other LULC types. Therefore, grasslands and croplands had smaller and more fragmented patches, which led to a decreased habitat potential.

According to the shape metrics group, the low MSI and AWMSI values of shrublands indicated more regular patch shapes that conduce to higher habitat values than other LULC types. On the contrary, bare land and croplands have small and irregular geometric patch shapes, which means lower habitat potential.

The core metrics group is important for protecting landscape values. According to it, forest areas had the highest values of TC and TCA, because forest areas lie in the middle of the watershed valley with low PN, MPS values, and low fragmentation, thus they had a higher habitat potential. Core areas of shrubland and bare land types were quite small, resulting in low habitat values.

According to landscape metrics results of isolation/contiguity metrics, croplands had the highest CONTIG_MN and ENN_MN values, which led to a decreased habitat potential. On the contrary, shrub areas had the lowest continuity and isolation values. Grasslands, forest and bare land, respectively, have similar habitat potential due to the topographic shape of deep valley.

The low ED of forest and grassland indicated that they had higher habitat values with more interior differences in the richness of species. PN of bare land was the highest with a low PD. Therefore, this LULC type became more fragmented than other types. Grasslands and croplands with high CONTIG_MN, ENN_MN and FRAG_MN values demonstrate more heterogeneous and fragmented habitats. Furthermore, croplands with low PN and AWMSI had a potential to shrink. Generally, croplands had the lowest habitat potential in this research, due to the fact that croplands had been decreasing since 1987, and the patches of croplands were quite fragmented and dispersed. The high values of TC, and CAI_MN in forest areas had high habitat potential, conversely, shrublands had the opposite effect. In addition, the low MPAR and FRAC_AM values of shrubs indicated a high habitat potential. In addition, shrublands with high PN, PD and low MSI means improved habitats. However, their habitat potential was lower due to their high ED, CONTIG_MN, ENN_MN and low MPS values, which mean a high level of fragmentation (Table 4).

According to the linear normalization of all metrics from 1987 to 2016, the habitat function of the LULC types from highest to lowest were forests, shrublands, croplands, grasslands and bare land, respectively (Figure 6). The habitat function of forests decreased suddenly in 1998 compared to other periods. This loss of forest habitat led to an increase in shrubland, cropland and bare land areas. The habitat potential of shrublands was the highest among the LULCC types in 1998, and the habitat value of bare land was the lowest. In 2016, forests experienced the highest habitat function at 1.00 due to uniform, compact and un-fragmented patches, followed by grasslands at 0.540. Bare land experienced the lowest habitat function at 0.00. This landscape structure analysis integrated with the normalization method is a first in terms of ranking the habitat changes of LULC on the same scale to provide a more objective approach.

The values of habitat function assess each LULCC pattern according to ecological integrity (Esbah et al., 2009; Demir and Demirel, 2018; Hussain et al., 2018). External influence should be considered in habitat function because unsustainable use and lack of administrative structure can negatively affect it (Bruton et al., 2016; Demir et al., 2016). 
Table 4. Landscape metrics of LULC (land use-land cover) from 1987 to 2016

\begin{tabular}{|c|c|c|c|c|c|c|c|c|c|c|c|c|c|c|c|c|c|c|c|c|c|}
\hline & \multicolumn{9}{|c|}{ Area/Edge Metrics } & \multicolumn{6}{|c|}{ Shape Metrics } & \multicolumn{3}{|c|}{ Core Metrics } & \multicolumn{3}{|c|}{ Isolation/Contiguity } \\
\hline \multirow{6}{*}{1987} & LULC & PLAND & $\mathrm{TE}$ & ED & PN & PD & MPS & AWMPS & Norm. & MSI & AWMSI & \begin{tabular}{|c|} 
FRAC \\
MN
\end{tabular} & $\begin{array}{c}\text { FRAC } \\
\text { AM }\end{array}$ & & Norm. & 1. TCA & \begin{tabular}{|l|} 
CAI \\
MN \\
\end{tabular} & Norm. & $\begin{array}{c}\text { CONTIG } \\
\text { MN }\end{array}$ & \begin{tabular}{|c|} 
ENN \\
MN \\
\end{tabular} & Norm. \\
\hline & Shrubland & 9.06 & 4100 & 4.11 & 322 & 0.45 & 0.68 & 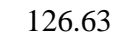 & 0.00 & 1.19 & 3.44 & 1.04 & 1.16 & 494.86 & 1.00 & 127.53 & 0.04 & 0.00 & 0.27 & 106.51 & 0.86 \\
\hline & Grassland & 28.57 & 436110 & 55.9 & 221 & 0.08 & 4.12 & 736.2 & 0.00 & 1.26 & 7.2 & 1.04 & 1.23 & 206.61 & 0.58 & 539.19 & 0.3 & 0.27 & 0.13 & 91.98 & 1.00 \\
\hline & Forest & 49.87 & 308730 & 39.58 & 68 & 0.02 & 42.76 & 3711.79 & 1.00 & 1.31 & 11.15 & 1.04 & 1.27 & 82.35 & 0.00 & 1900.53 & 0.65 & 1.00 & 0.2 & 95.17 & 0.94 \\
\hline & Bare land & 11.29 & 233700 & 29.96 & 174 & 0.14 & 3.18 & 128.86 & 0.20 & 1.36 & 4.33 & 1.05 & 1.19 & 285.72 & 0.04 & 76.05 & 0.27 & 0.05 & 0.26 & 119.6 & 0.86 \\
\hline & Cropland & 10 & 19740 & 2.53 & 17 & 0.53 & 5.52 & 12.47 & & 1.38 & 1.51 & 1.07 & 1.08 & 226.49 & 0.28 & 9.9 & 2.59 & 0.80 & 0.69 & 767.56 & 0.00 \\
\hline \multirow{6}{*}{1998} & LULC & PLAND & TE & ED & PN & PD & $\begin{array}{c}\text { AREA } \\
\text { MN }\end{array}$ & $\begin{array}{l}\text { AREA } \\
\text { AM }\end{array}$ & Norm. & \begin{tabular}{|c|} 
SHAPE \\
MN
\end{tabular} & $\begin{array}{c}\text { SHAPE } \\
\text { AM }\end{array}$ & \begin{tabular}{|c|} 
FRAC \\
MN
\end{tabular} & $\begin{array}{c}\text { FRAC } \\
\text { AM }\end{array}$ & $\begin{array}{c}\text { PARA } \\
\text { AM }\end{array}$ & Norm. & TCA & \begin{tabular}{|l|} 
CAI \\
MN \\
\end{tabular} & Norm. & $\begin{array}{c}\text { CONTIG } \\
\text { MN }\end{array}$ & \begin{tabular}{|c|} 
ENN \\
MN
\end{tabular} & Norm. \\
\hline & Shrubland & 50 & 0140 & 30.61 & 1540 & 1.18 & 27.86 & 3586.5 & 1.00 & 1.21 & 7.72 & 1.04 & 1.23 & 64.47 & 1.00 & 2604.42 & 0.82 & 1.00 & 0.27 & 106.51 & 0.86 \\
\hline & Grassland & 24.62 & 528030 & 49.39 & 1100 & 0.43 & 4.03 & & 00 & 1.29 & & & 1.2 & 212.88 & 0.46 & 552.87 & 0.47 & .23 & 0.13 & & 00 \\
\hline & Forest & 14.12 & 304890 & 49.65 & 234 & 0.05 & 2 & 127.4 & 0.43 & 1.33 & 4.32 & 1.05 & 1.2 & 359.48 & 0.00 & 122.22 & 0.07 & 0.00 & 0.2 & 95.17 & 0.94 \\
\hline & Bare land & 10.25 & 187800 & 25.6 & 672 & 0.55 & 3.11 & & & 1.31 & 4.68 & 1.05 & 1.2 & 268.3 & 0.24 & 105.84 & 0.24 & 0.03 & 0.26 & & 0.86 \\
\hline & Cropland & 1.01 & 14880 & 1.92 & 14 & 0.16 & 6.07 & 12.96 & 0.85 & 1.34 & 1.48 & 1.06 & 1.07 & 207.53 & 0.71 & 9.99 & 4.22 & 0.84 & 0.69 & 767.56 & 0.00 \\
\hline \multirow{6}{*}{2009} & LULC & PLAND & TE & ED & $\mathrm{PN}$ & PD & $\begin{array}{c}\text { AREA } \\
\text { MN }\end{array}$ & $\begin{array}{l}\text { AREA } \\
\text { AM }\end{array}$ & Norm. & $\begin{array}{c}\text { SHAPE } \\
\text { MN }\end{array}$ & $\begin{array}{c}\text { SHAPE } \\
\text { AM }\end{array}$ & $\begin{array}{l}\text { FRAC } \\
\text { MN }\end{array}$ & $\begin{array}{c}\text { FRAC } \\
\text { AM }\end{array}$ & \begin{tabular}{|c|} 
PARA \\
AM
\end{tabular} & Norm. & TCA & $\begin{array}{l}\text { CAI } \\
\text { MN }\end{array}$ & Norm. & $\begin{array}{c}\text { CONTIG } \\
\text { MN }\end{array}$ & $\begin{array}{l}\text { ENN } \\
\text { MN }\end{array}$ & Norm. \\
\hline & Shrubland & 13.81 & 460140 & 58.98 & 375 & 0.34 & 0.89 & 185.05 & 0.23 & 1.19 & 4.18 & $\mid 1.03$ & 1.19 & 435.65 & 1.00 & 187.29 & 0.04 & 0.00 & 0.26 & 105.75 & 0.87 \\
\hline & Grassland & 29.85 & 528030 & 67.69 & 247 & 0.08 & 4.29 & 806.42 & 0.20 & 1.28 & 10.18 & 1.04 & 1.27 & 237.25 & 0.00 & 363.24 & 0.16 & 0.12 & 0.13 & 90.12 & 1.00 \\
\hline & Forest & 46.45 & 304890 & 39.08 & 68 & 0.02 & 43.66 & 3379.73 & 1.00 & 1.33 & 11.29 & 1.04 & 1.28 & 87.19 & 0.01 & 1667.79 & 0.93 & 1.00 & 0.19 & 99.86 & 0.94 \\
\hline & Bare land & 8.92 & 187800 & 24.07 & 159 & 0.16 & 2.91 & 134.22 & 0.00 & 1.34 & 4.43 & 1.05 & 1.19 & 291.22 & 0.21 & 56.43 & 0.3 & 0.00 & 0.29 & 139.59 & 0.80 \\
\hline & Cropland & 0.96 & 14880 & 1.91 & 12 & 0.4 & 5.75 & 13.5 & 0.21 & 1.38 & 1.48 & 1.07 & 1.07 & 217.41 & 0.54 & 9.09 & 3.2 & 0.76 & 0.69 & 550.56 & 0.00 \\
\hline \multirow{6}{*}{2016} & LULC & PLAND & TE & ED & PN & PD & $\begin{array}{c}\text { AREA } \\
\text { MN } \\
\end{array}$ & $\begin{array}{l}\text { AREA } \\
\text { AM }\end{array}$ & Norm. & $\begin{array}{c}\text { SHAPE } \\
\text { MN }\end{array}$ & \begin{tabular}{|c|}
$\begin{array}{c}\text { SHAPE } \\
\text { AM }\end{array}$ \\
\end{tabular} & \begin{tabular}{|c|} 
FRAC \\
MN \\
\end{tabular} & $\begin{array}{c}\text { FRAC } \\
\text { AM }\end{array}$ & \begin{tabular}{|c|} 
PARA \\
AM
\end{tabular} & Norm. & TCA & \begin{tabular}{|l|} 
CAI \\
MN \\
\end{tabular} & Norm. & $\begin{array}{c}\text { CONTIG } \\
\text { MN }\end{array}$ & $\begin{array}{l}\text { ENN } \\
\text { MN }\end{array}$ & Norm. \\
\hline & Shrubland & 9.25 & 128670 & 16.49 & 01 & 0.09 & 2.56 & 538.08 & 0.00 & 1.15 & 5.45 & 1.03 & 1.21 & 185.91 & 1.00 & 304.38 & 0.17 & 0.05 & 0.12 & 112.02 & 1.00 \\
\hline & Grassland & 27.61 & 421050 & 53.97 & 185 & 0.07 & 4.09 & 229.93 & 0.13 & 1.22 & 4.87 & 1.04 & 1.21 & 205.1 & 0.70 & 522.18 & 0.55 & 0.28 & 0.28 & 92.91 & 0.87 \\
\hline & Forest & 43.93 & 295140 & 37.83 & 62 & 0.02 & 55.27 & 3235.1 & 1.00 & 1.41 & 11.45 & 1.05 & 1.28 & 89 & 0.18 & 1472.04 & 0.97 & 1.00 & 0.18 & 98.52 & 0.96 \\
\hline & Bare land & 18.29 & 304170 & 38.99 & 180 & 0.09 & 6.61 & 341.9 & 0.09 & 1.39 & 7.65 & 1.05 & 1.25 & 229.93 & 0.00 & 155.07 & 0.36 & 0.00 & 0.29 & 116.82 & 0.84 \\
\hline & Cropland & 0.93 & 13650 & 1.75 & 12 & 0.7 & 6.08 & 12.62 & 0.24 & 1.37 & 1.42 & 1.06 & 1.06 & 205.76 & 0.61 & 9.63 & 3.9 & 0.80 & 0.69 & 693.71 & 0.00 \\
\hline
\end{tabular}

PLAND: Percentage of Landscape, MPS: Mean Patch Size, AWMPS: Area Weighted Mean, PN: Patch Number, PD: Patch Density, TE: Total Edge, ED: Edge Density, MSI: Mean Size Index, AWMSI: Area Weighted Mean size Index, MPAR: Area Weighted Mean Perimeter-area Ratio, FRAC-AM: Area Weighted Mean Fractal, CONTIG_MN: Mean Contiguity, ENN_MN: Mean Euclidean Nearest Neighbors Distance, TCA: Total Core Area, CAI_MN: Mean Core Area Index 
For example, more than $40 \%$ of the uncontrolled wood cutting of local people and road networks in 1998 represented a key factor in the decline of forest habitats in Mary Valley. The habitat function of landscape patterns is calculated using different types of landscape metrics and indicates direct or inverse effects (Malaviya et al., 2010; Fichera et al., 2012). All metrics were evaluated separately, depending on their direct or inverse relationships with the habitat function changes of each LULC types through the linear normalization (Norm.) called Min-Max method (Figure 6). As a result, objective values for the habitat function of all LULC types were calculated. This normalization statistical technique was an effective and easy way to enhance our understanding and to measure the effects of metrics on habitat function. A high number of metrics creates difficulties for the evaluation of habitat function (Esbah et al., 2009; Fichera et al., 2012; Bruton et al., 2016). A research was suggested to limit and categorize them using a statistical method such as factor or cluster analysis with the assistance of an expert (Mairota et al., 2013). Thus the 16 metrics selected were categorized in 4 groups based on their characteristics and were evaluated objectively using linear normalization method.

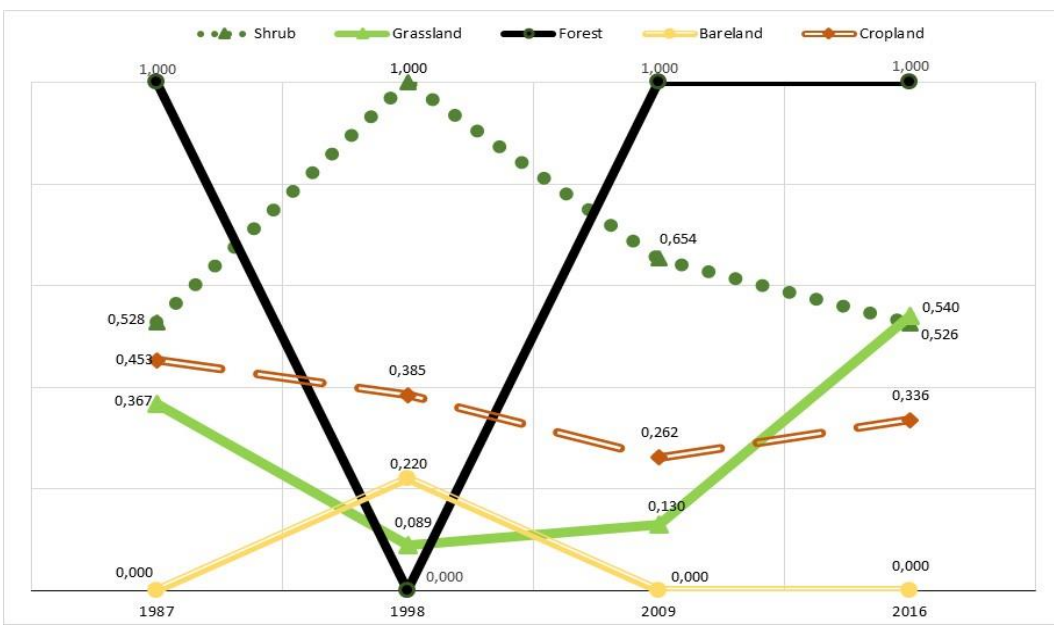

Figure 6. Total habitat changes (ha) of LULC (land use-land cover) by linear normalization

\section{LULC change of endemic plant areas}

Changes in the endemic plant habitats were compared with the habitat function of each LULC type. The changes in these species' distribution areas were inversely related to the habitat function of bare land and forest areas, but directly related to habitat function of shrublands (Figure 7). In the grasslands, the endemic plants habitats were inversely related to habitat function. The results of these analyses, conducted along the distribution areas of endemic plants, has allowed detecting a significant relationship with the habitat function of LULC.

The decline in shrublands diminished the habitat function of endemic plant distribution areas. Generally, shrublands have a valuable habitat status for endemic plants (Salapaş, 2002; Estes et al., 2012; Bruton et al., 2016). Thus, the transformation of shrublands should be stopped to protect the species. Bare land areas have increased over 29 years and adversely affected the habitat function of sensitive, unique and rare endemic plant habitats. The rise in the total area of bare land should also be reduced to prevent negative effects. Unlike the bare land trend, forest area inversely affected them. 
This method is a first in terms of identifying changes in endemic plant habitats to prove the effect of LULC type changes on sensitive habitats.

Endemic plants are located in different LULC types (Uzun, 2002; Estes et al., 2012; Scullion et al., 2014). Due to this reason, future conservation decisions can be prepared based on the separate environmental requirements of endemic plants to sustain each habitat function. Uncontrolled tree cutting and infrastructure expansion connect the decline of the habitat function of forest areas to the increase in bare land and grassland habitat functions based on area/edge, shape, core and isolation/contiguity metrics. Since 1998, the habitat function of forest areas for endemic plants has increased. This result showed that forest habitat renewed itself with ecological processes. Conservation and management plans should respect ecological processes to ensure the ecological integrity of the research area.

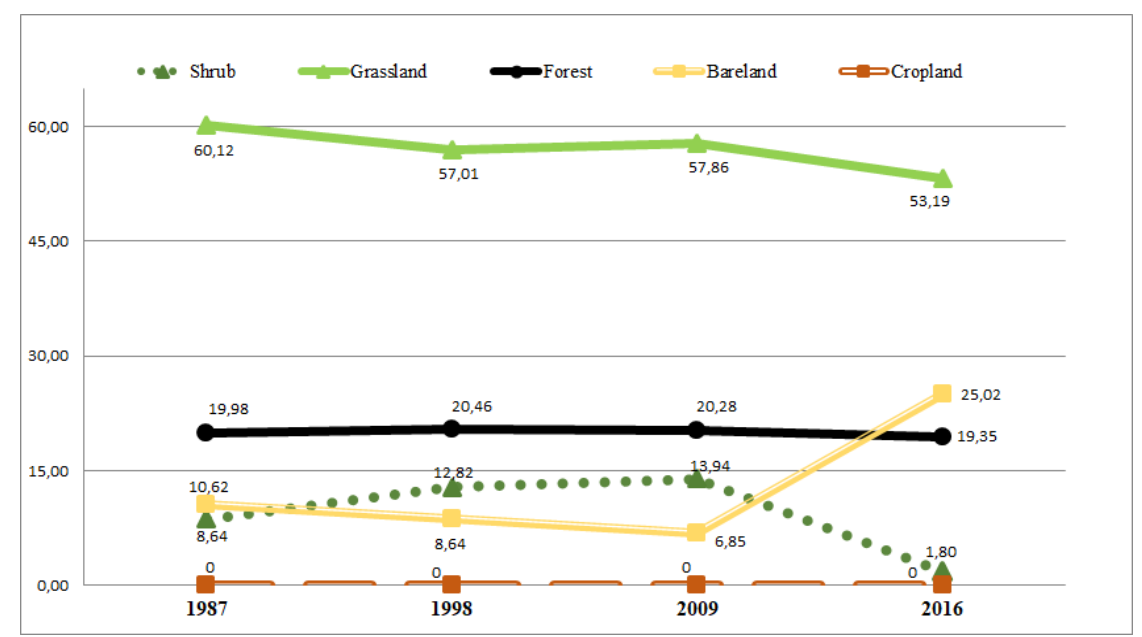

Figure 7. LULC (land use-land cover) change of endemic plant areas (ha) from 1987 to 2016

\section{Other related changes}

The spatial and temporal monitoring model supplied quantitative results of past to present day changes and can estimate the direction and extent of future transformation (Malaviya et al., 2010; Fichera et al., 2012; Mairota et al., 2013) However, this research has some limitations. It is still too difficult to determine the unpredictable effect of other changes such as decreasing local population and insufficient visitor management. Local people play an important role in the protection of their own landscape resources (Chaminuka et al., 2012; Estes et al., 2012; Fichera et al., 2012; Scullion et al., 2014; Demir et al., 2016). Nevertheless, according to data of TURKSTAT (2016), the population decreased from 4,142 in 1987 to 1,605 in 2016 in Mary Valley's protected area. Demographic projections for Mary Valley (Demir et al., 2015; Demir, 2017) forecast that this declining trend will continue until 2040 (1,373 in 2020 and 743 in 2040). This decline was due to restrictions within the boundaries of the national park banning forestry and agricultural activities. The forestry area had constantly decreased since 1987 due to mostly uncontrolled deforestation and new road infrastructure. Another limitation was related to climate, which restricts tourism activities to July and August.

The research area is part of a valuable national park with tourism and recreation potential (Demir et al., 2015; Pirselimoglu and Demirel, 2015a, 2015b). Consequently, 
a future conservation plan and ecotourism activities with local cooperation in participatory management can be offered as a way to partially solve the problems of the natural environment and the populace (Estes et al., 2012; Francisco and Hochshil, 2012). Such a plan and ecotourism can create socio-economic prosperity for local people to return to the valley and protect its natural and cultural landscape. Local awareness on the protection of ecological values can be raised. All protection rules and ecotourism activities can be controlled by an interdisciplinary scientific council responsible to the related ministries, experts and other stakeholders. This can make it possible to provide special local protection and effectively prevent smuggling of the area's fauna, flora and historical resources.

In the study area, there is no capacity control or monitor visitors of the national park or tourism and recreation activities in general. These problems can put pressure on its ecological and cultural values and diminish its environmental characteristics. Thus, while conservation oriented plans are being made, tourism management and land resource management strategies based on landscape planning can be carefully considered not only for the national park, but for the entire catchment area in a future research. This method can be an efficient and effective way for future researches to monitor LULCC and habitat function worldwide and to determine conservation and management strategies.

In relevant literature, there are many studies in which LULC change detection and habitat change is studied. However, there researches on protected areas are quite limited, especially where changes of endemic plants habitat and the evaluation of landscape metrics by grouping are involved. Similar to Mary Valley's research, the Mairota et al. (2013) developed a quantitative method based on landscape structure metrics to monitor protected areas. It only analyzed the landscape structure of protected areas, but LULC changes from past to present day could be an important key element to monitor habitat function change of landscape dynamics to support the findings. On the contrary, in the research of Mary Valley, the effect of LULC changes on endemic plants was monitored with change detection and landscape metrics (individually and in four groups) which has an important role in improving sustainable planning and management strategies for the protected area. Malaviye et al. (2010) monitored 34 years of LULC changes to determine changes of habitat diversity of a mining area. Fichera et al. (2012) analyzed and monitored 50 years of LULC and habitat changes. The oldest image dated back to only the year 1987 of Marry Valley, because the satellite images of this study area were limited due to cloudy days and snow cover on highlands. Therefore, for the further research, the images of the study area should date back to before the conservation status was established, to provide an exhaustive analysis of want went on before and after that date. Although these researches analyzed LULC and habitat change in spatial and temporal scales using change detection and a few landscape structures metrics, they did not consider the relationship of LULC and habitat change with the endemic plants of the area, and neither did they group landscape metrics to qualify the landscape structure of LULC and endemic plant habitats. Furthermore, the main difference between Mary Valley' research and these sample studies is that the spatial and temporal LULC and habitat changes of protected area under four landscape metric groups, paired with the relationship of endemic plants were all analyzed. Therefore, these methods were developed to contribute guidance to future researches and practices worldwide. 


\section{Conclusions}

The objectives of this study were to determine temporal habitat function based on landscape structure analysis using landscape metrics and to identify the relationships between the change of LULC, habitat function and endemic plant distribution areas by temporal and spatial monitoring and analysis. First of all, changes of LULC and endemic plant areas were monitored, followed by habitat function of LULC types and endemic plant distribution areas, based on related studies conducted nationally and internationally. Through landscape habitat and landscape structure analysis, the temporal changes of LULC, endemic plants and habitats were determined for the research area. Mary Valley protected area has a catchment and archeological site. However, this research area has been under pressure due to habitat changes of LULC types and endemic plants distribution areas. Therefore, connectivity of landscape patches of each LULC types can be improved for sustainability, and ecological and cultural integrity of the study area, through establishing healthier conservation and management strategies by improving existing ones.

This research examined habitat function of LULC and endemic plants distribution areas based on landscape sensitivity, using landscape dynamics. The spatial and temporal landscape pattern was investigated on four different dates (over 29 years), which enabled us to monitor the changes of landscape dynamics. According to the findings on LULC change with change detection, forest areas lost the most area, whereas bare land areas significantly increased, gaining most of it from lost forests, grasslands and croplands. Furthermore, the most endemic plants are located in grasslands, although the highest loss and net change amounts were also indicated in grasslands. In addition, shrublands were under threat with a sharp constant decline trend. In the context of habitat function of LULC types and endemic plant distribution areas evaluated using landscape structure metrics with linear normalization scale, the endemic plant distribution areas had adverse effects on habitat function due to the edge effect, which diminished environmental resources. The forest had the highest, while bare land had the lowest habitat potential with high fragmentation. This study evaluated temporal LULC and habitat changes. In this research, the landscape structure analysis integrated with normalization method and the determination of the effects of LULC changes on sensitive endemic plants habitats were a first, and thus these new approaches may set an example for future studies related LULC and LULC changes on sensitive areas. These methods and findings can help control sensitive landscape dynamics for further sustainable development of protected areas. Thus, this research can set an example for Turkey and other developing countries in supporting the sustainability of ecological and cultural integrity of protected areas.

Acknowledgements. I am grateful to Professors Jiquan Chen and Assoc. Professors Ranjeet Kumar for their valuable and constructive comments on this paper.

\section{REFERENCES}

[1] Angonese, J. G., Grau, H. R. (2014): Assessment of swaps and persistence in land cover changes in a subtropical periurban region, NW Argentina. - Landsc. Urban Plan. 127: 8393. doi:10.1016/j.landurbplan.2014.01.021. 
[2] Antrop, M. (2000): Changing patterns in the urbanized countryside of Western Europe. Landsc Ecol 15(3): 257-270.

[3] BirdLife International. (2015): Important Bird and Biodiversity Area factsheet: Eastern Black Sea Mountains. - cited 2015 Apr 16. Available from: http://www.birdlife.org.

[4] Bozkaya, A. G., Balcik, F. B., Goksel, C., Esbah, H. (2015): Forecasting land-cover growth using remotely sensed data: a case study of the Igneada protection area in Turkey. - Environmental monitoring and assessment 187: 59-77. doi:10.1007/s10661-015-4322-z

[5] Braimoh, A. K. (2006): Random and systematic land-cover transitions in northern Ghana. - Agric. Ecosyst. Environ. 113: 254-263.

[6] Bruton, M. J., Maron, M., Franklin, C. E., McAlpine, A. A. (2016): The relative importance of habitat quality and landscape context for reptiles in regenerating landscapes. - Biological Conservation 193: 37-47.

[7] CE (Council of Europe). (2000): The European Landscape Convention. - European Treaty Series No: 176, Florence, Italy.

[8] Chaminuka, P., Groeneveld, R. A., Salomane, A. O., Van Ierland, E. C. (2012): Tourist preferences for ecotourism in rural communities adjacent to Kruger National Park: a choice experiment approach. - Tourism Management 33: 168-176.

[9] Congalton, R., Gu, J., Yadav, K., Thenkabail, P., Ozdogan, M. (2014): Global Land cover mapping: a review and uncertainty analysis. - Remote Sensing 6: 12070-12093. doi:10.3390/rs61212070.

[10] Demir, S., Demirel, O., Erdogan, M. A., Akyol, M., Bayramoglu, E. (2015): "Determining protective tourism strategies through visibility analysis: Altindere valley national park case" - IFLA 2015 Congress June 7-15. Full paper: pp:453-460. http://tr.scribd.com/doc/270375967/52nd-IFLA-Word-Congress-2015-Proceedings.

[11] Demir, S., Esbah, H., Akgün, A. A. (2016): Quantitative SWOT Analysis for Prioritizing Ecotourism Planning Decisions in Protected Areas: Igneada Case. - International Journal of Sustainable Development and World Ecology. Doi: 10.1080/13504509.2015.1136709.

[12] Demir, S. (2017): Landscape Planning Based on Nature Conservation-Tourism in the Context of Historical Landscape and Landscape Character Assessment Approaches: Mary Valley Sample. - PhD Thesis, Karadeniz Twchnical University, Landscape Architecture, Trabzon, Turkey.

[13] Demir, S., Demirel, Ö. (2018): Landscape Ecology Approach in Landscape Planning. Turkish Journal of Landscape Research 1(1): 1-8.

[14] Development Plan (2005): Altindere Valley National Park Long Term Development Plan Analytical Survey Report. - T.C. Ministry of Forest and Water, General Directorate of Nature Conservation and National Parks, Belda Project and Consulting Trade Limited Company, Ankara.

[15] Doganay, S. (2003): Altindere valley national park in view of its geographical features. East. Geo. Rev. 8(10).

[16] DOKA (Development Agency od Eastern Black sea of Turkey). (2012): Determining and Mappinh of Alternative Tourism Potential of Mary Valley. - Karadeniz Technical University, Turkey, TR 90/10/TUR IZM001-A.

[17] Erdogan, M. A., Esbah, H., Berberoglu, S. (2013): Modeling land use/land cover conversion risk. - ITU AZ Journal 10(2): 67-80.

[18] Esbah, H., Edward, A. C., Ewan, J. (2009): Effects of Increasing Urbanization on the Ecological Integrity of Open Space Preserves. - Environmental Management 43: 846862.

[19] Esbah, H., Deniz, B., Kara, B., Kesgin, B. (2010): Analyzing landscape changes in the Bafa Lake Nature Park of Turkey using remote sensing and landscape structure metrics. Environ. Monit. Assess 165: 617-632. doi:10.1007/s10661-009-0973-y.

[20] Esbah, H., Erdogan, M. A., Tanriover, A. (2011): Cellular automata-markov chain and landscape metrics for landscape planning. - ITU AZ Journal 8(2): 63-79. 
[21] Estes, A. B., Kuemmerle, T., Kushnir, H., Radeloff, V. C., Shugart, H. H. (2012): Landcover change and human population trends in the greater Serengeti ecosystem from 1984-2003. - Biological Conservation 147: 255-263.

[22] Fan, K., Pei, W. J., Zhang, J. S., Yu, J. X., Zeng, W. J. (2018): Analysis on Landscape pattern of land use and eco-environment characteristics of three lake basins in Yunnan Province, China. - Applied Ecology And Environmental Research 16(5): 5693-5704.

[23] Fichera, C. R., Modica, G., Pollino, M. (2012): Land Cover classification and changedetection analysis using multi-temporal remote sensed imagery and landscape metrics. European Journal of Remote Sensing 45(1): 1-18.

[24] Forman, R. T. T., Godron, M. (1986): Landscape Ecology. - University of Minnesota, Willey, New York, NY, USA.

[25] Francisco, J., Hochschil, V. (2012): Land Use and Land Cover (LULC) Change in the Boconó River Basin, North Venezuelan Andes, and Its Implications for the Natural Resources Management. - In: Appiah-Opoku, S. (ed.) Environmental Land Use Planning. InTech, pp. 35-68. doi:10.5772/50678.

[26] Ghosh, A., Munshi, M., Areendran, G., Joshi, P. K. (2012): Pattern space analysis of landscape metrics for detecting changes in forests of Himalayan foothills. - Asian Journal of Geoinformatics 12(1).

[27] GLC30 (Global Land Cover). (2015): Trabzon land cover map 2010. - cited 2015 August 24. Available from: http://www.globallandcover.com/GLC30Download/index.aspx.

[28] Gökyer, E. (2013): Understanding Landscape Structure Using Landscape Metrics, Advances in Landscape Architecture. - In: Özyavuz, M. S. (ed.) Advances in Landscape Architecture. InTech, pp. 663-676. doi: 10.5772/55758.

[29] Hussain, K., Haq, F., Rahman, F. (2018): Shrinking greenery: Land use and land cover changes in Kurram Agency, Kohi Safid Mountains of north-western Pakistan 15(2): 296306.

[30] KAMAG (The Public Institutions for Research and Development of Turkey). (2011): Determining Politic and Strategic Improving of Rural Areas in Trabzon-Samsun-Konya Regions focused on Protection: Proposal a Model for Rural Area Planning. - Karadeniz Technical University, Turkey.

[31] Kara, B., Esbah, H., Deniz, B. (2013): Monitoring and analyzing land use/land cover changes in a developing coastal town: A case study of Kusadasi, Turkey. - Journal of Coastal Research 29(6): 1361-1372.

[32] Lausch, A., Herzog, F. (2002): Applicability of landscape metrics for the monitoring of landscape change: issues of scale, resolution and interpretability. - Ecological Indicators 2(1): $3-15$

[33] Leitao, A. B., Miller, J., Ahern, J., McGarigal, K. (2006): Measuring landscapes: a planner's handbook. - Island Pres, Washington, DC.

[34] Mairota, P., Cafarelli, B., Boccaccio, L., Leronni, V., Labadessa, R., Kosmidou, V., Nagendra, H. (2013): Using landscape structure to develop quantitative baselines for protected area monitoring. - Ecological Indicators 33: 82-95.

[35] Malaviya, S., Munsi, M., Oinam, G., Joshi, P. K. (2010): Landscape approach for quantifying land use land cover change (1972-2006) and habitat diversity in a mining area in Central India (Bokaro, Jharkhand). - Environmental monitoring and assessment 170(1-4): 215-229.

[36] Martinuzzi, S., Radeloff, V. C., Joppa, L. N., Hamilton, C. M., Helmers, D. P., Plantinga, A. J., Lewis, D. J. (2015): Scenarios of future land use change around United States' Protected Areas. - Biological Conservation 184: 446-455.

[37] McGarigal, K., Marks, B. J. (1995): Fragstats: Spatial pattern analysis program for quantifying landscape structure. - Report, Portland: USDA Forest Service, Pacific Northwest Research Station. 
[38] McGarigal, K., Cushman, A. S, Neel, C. M., Ene, E. (2012): Fragstats: spatial pattern analysis program for categorical maps, Version 4.2. - Amherst, Massachusetts: University of Massachusetts.

[39] Neel, M. C. (2008): Patch connectivity and genetic diversity conservation in the federally endangered and narrowly endemic plant species Astragalus albens (Fabaceae). Biological Conservation 141(4): 938-955.

[40] Oinam, S. S., Rawat, Y. S., Khoiyangbam, R. S., Gajananda, K., Kuniyal, J. C., Vishvakarma, S. C. R. (2018): Land use and land cover changes in Jahlma watershed of the Lahaul valley, cold desert region of the northwestern Himalaya, India. - Journal of Mountain Science 2(2): 129-136.

[41] Özyavuz, M., Satir, O., Bilgli, B. C. (2011): A change vector analysis technique to monitor land-use / landcover in the Yildiz Mountains, Turkey. - Fresenius Environmental Bulletin 20(5): 1190-1199.

[42] Pirselimoğlu, Z. B., Demirel, Ö. (2015a): Ecology-Based Tourism Potential With Regard to Alternative Tourism Activities in Altindere Valley (Trabzon - Maçka). - International Journal of Sustainable Development and World Ecology 22(1): 39-49. doi:10.1080/13504509.2014.948098.

[43] Pirselimoğlu, Z. B., Demirel, Ö. (2015b): Natured based tourısm actıvity in the route of Altindere Valley Mary creek route: paragliding. - İnönü University Journal of Art and Design 5(11): 13-26.

[44] Rawat, J. S., Kumar, M. (2015): Monitoring land use/cover change using remote sensing and GIS techniques: A case study of Hawalbagh block, district Almora, Uttarakhand, India. - Egypt. J. Remote Sens. Space Sci 18: 77-84. doi:10.1016/j.ejrs.2015.02.002.

[45] Salapaş, S. (2002): Sunalpine and alpine of Altindere Valley (Maçka -Trabzon). - Master Thesis. 147 p. Karadeniz Technical Univetsity, Forestry Faculty.

[46] Scullion, J. J., Vogt, K. A., Sienkiewiez, A., Gmur, S. J., Trujillo, C. (2014): Assessing the influence of land-cover change and conflicting land-use authorizations on ecosystem conversion on the forest frontier of Madre de Dios, Peru. - Biological Conservation 171: 247-258.

[47] Seto, K. C., Fragkias, M. (2005): Quantifying Spatiotemporal Patterns of Urban Land-use Change in Four Cities of China with Time Series Landscape Metrics. - Landsc Ecol 20: 871-888. doi:10.1007/s10980-005-5238-8.

[48] Tian, Y., Yin, K., Lu, D., Hua, L., Zhao, Q., Wen, M. (2014): Examining Land Use and Land Cover Spatiotemporal Change and Driving Forces in Beijing from 1978 to 2010. Remote Sensing 6(11): 10593-10611. doi:10.3390/rs61110593.

[49] TURKSTAT (Turkish Statistical Institute). (2016): Population, demography, residental, social structure, provincial and municipal districts according to population Macka. - cited 2016 Dec 09. Available from: https://biruni.tuik.gov.tr/adnksdagitapp/adnks.zul.

[50] Turner, M. G., Gardner, R. H., O’Neill, R. V. (2001): Landscape ecology in theory and practice. - Pattern and Precess. Newyork:Springer.

[51] Uzun, A. (2002): Flora of forest vegetation of Altindere Valley (Maçka-Trabzon). Master Thesis 151 p. Karadeniz Technical Univetsity, Forestry Faculty.

[52] Wang, X., Cumming, S. G. (2011): Measuring landscape configuration with normalized metrics. - Landscape Ecology 26: 723-736.

[53] Yale (2015): Filling Gaps in Landsat ETM Images. - cited 2015 Nov 20. Available from: http://www.yale.edu/ceo/Documentation/Landsat_ETM_Gap_Fill.pdf.

[54] Yavuz, S., Deveci, M. (2013): The Effect of Statistical Normalization Techniques on The Performance of Artificial Neural Network. - Erciyes University Faculty of Economics and Administrative Sciences Journal 40: 167-187.

[55] Zaman, M. (2010): One of the major religious tourism center of Turkey: Sumela (Mary) Monastery. - J. Grad. Soc. Sci 6: 1-24. 


\section{APPENDIX}

Appendix 1. The endemic plants of Mary Valley based on IUCN category (Salapaş, 2002; Uzun 2002; Demir, 2017)

\begin{tabular}{|c|c|c|}
\hline IUCN & Taxonomy & Family \\
\hline VU & Alchemilla oriturcica & Rosaceae \\
\hline VU & Symphytum longipetiolatum & Boraginaceae \\
\hline VU & Jasione supina subsp. pontica & Campanulaceae \\
\hline VU & Crocus aerius & Iridaceae \\
\hline $\mathrm{LR}(\mathrm{nt})$ & Sempervivum minus var. glabrum & Crassulaceae \\
\hline $\mathrm{LR}(\mathrm{nt})$ & Cirsium trachylepis & Asteraceae(Compositae) \\
\hline $\mathrm{LR}(\mathrm{nt})$ & Alchemilla sintenisii & Rosaceae \\
\hline $\mathrm{LR}(\mathrm{nt})$ & Potentilla cappadocica & Rosaceae \\
\hline $\mathrm{LR}(\mathrm{nt})$ & Astragalus lineatus var.jildisianus & Fabaceae \\
\hline $\mathrm{LR}(\mathrm{nt})$ & Sempervivum minus var. minus & Crassulaceae \\
\hline $\mathrm{LR}(\mathrm{nt})$ & Alchemilla sintenisii & Rosaceae \\
\hline LR(lc) & Ranunculus dissectus subsp. huetii & Ranunculaceae \\
\hline $\mathrm{LR}(\mathrm{lc})$ & Cerastium gnaphalodes & Caryophyllaceae \\
\hline $\mathrm{LR}(\mathrm{lc})$ & Draba rigida var. rigida & Brassicaceae (Criciferae) \\
\hline $\mathrm{LR}(\mathrm{lc})$ & Trifolium pannonicum subsp. elongatum & Fabaceae \\
\hline $\mathrm{LR}(\mathrm{lc})$ & Heracleum platytaenium & Apiaceae (Umbelliferae) \\
\hline $\mathrm{LR}(\mathrm{lc})$ & Galium fissurense & Rubiaceae \\
\hline $\mathrm{LR}(1 \mathrm{c})$ & Tripleurospermum monticolum & Asteraceae(Compositae) \\
\hline $\mathrm{LR}(\mathrm{lc})$ & Cirsium sommieri & Asteraceae(Compositae) \\
\hline $\mathrm{LR}(\mathrm{lc})$ & Geranium asphodeolides subsp. sintensii & Geraniaceae \\
\hline $\mathrm{LR}(\mathrm{lc})$ & Geranium ibericum subsp. jubatum & Geraniaceae \\
\hline $\mathrm{LR}(\mathrm{lc})$ & Muscari aucheri & Liliaceae \\
\hline $\mathrm{LR}(\mathrm{lc})$ & Muscari coeleste & Liliaceae \\
\hline $\mathrm{LR}(\mathrm{lc})$ & Dactylorhiza osmanica var. osmanica & Orchidaceae \\
\hline $\mathrm{LR}(\mathrm{lc})$ & Cyclamen parviflorum & Primulaceae \\
\hline $\mathrm{LR}(\mathrm{lc})$ & Phlomis russeliana & Lamiaceae(Labiatae) \\
\hline $\mathrm{LR}(\mathrm{lc})$ & Lamium ponticum & Lamiaceae(Labiatae) \\
\hline $\mathrm{LR}(\mathrm{lc})$ & Campanula betulifolia & Companulaceae \\
\hline $\mathrm{LR}(\mathrm{lc})$ & Lonicera caucasica subsp. orientalis & Caprifoliaceae \\
\hline $\mathrm{LR}(\mathrm{cd})$ & Cerastium lazicum & Caryophyllaceae \\
\hline $\mathrm{LR}(\mathrm{cd})$ & Festuca amethystina subsp. orientalis var. turcica & Poaceae (Gramineae) \\
\hline
\end{tabular}

VU: Vulnerable, LR(nt): Near Threatenes, LR(lc): Least Concern, LR(cd): Critically Endangered 